International Journal of Environment, Agriculture and Biotechnology
Vol-6, Issue-3; May-Jun, 2021
JUEB
$\begin{gathered}\text { Journal Home Page Available: } \text { https://ijeab.com/ } \\ \text { Journal DOI: } 10.22161 / \text { ijeab }\end{gathered}$

Article

Peer-Reviewed Journal

\title{
Analysis of Quality of Landrace Rice: AG4 variety in An Giang, Vietnam
}

\author{
Nguyen thi Lang, Le Hoang Phuong, Bui Chi Hieu, Bui Chi Buu
}

High Agricultural Technology Research Institute for Mekong delta, VietNam

Received: 01 Apr 2021; Received in revised form: 07 May 2021; Accepted: 20 May 2021; Available online: 08 Jun 2021 (C)2021 The Author(s). Published by Infogain Publication. This is an open access article under the CC BY license (https://creativecommons.org/licenses/by/4.0/).

\begin{abstract}
Landrace rice genotypes AG4 were evaluated inTri Ton, Tinh Bien, AnGiang Province with three replications in a field experiment during 2019 to 2020. The analysis revealed significant differences among the genotypes against all the characters studied. In general, phenotypic variance is higher than the corresponding genotypic variance for all the characters studied. AG4 rice is considered as the unique landrace varietal group because of its aroma and superior grain quality.To confirm the presence or absence of fragrance in AG 4, a set of 11 lines was phenotypedby using gas chromatographic separation to quantify $2 A P$ content in milled rice samples. KOH tested and PCR method with two directives RM223 and FMU1-2 are recorded to select the lines with the best fragrance followed by line7, 10,14 and 20.The shape is determined by the length and width ratio.From shape evaluation, length and width ratio of AG4 are high. Level of chalkiness is. There are mostly low contents on AG4, when doing rice quality analysing. It is the evidence for the deliciousness on rice. Milling quality determines the final yield and fracture rate of milled rice. Recorded line 7 for high milling rate is over 50\%. Protein content of rice varieties ranges from 6.9 to $8.6 \%$. Lines 7 and 56 have the highest protein content (8.5-8.6\%). Characters like number of panicles per plant, panicle weightg, number of grains per panicle, and grain yield recorded are high. Grain yield analysis revealed significant differences among lines. Selected AG4, lines number 7 can be used in breed selection program in the nearest future to provide the local need.
\end{abstract}

Keywords-aroma, amylose, chalkiness, genotypic, phenotypic, milling quality.

\section{INTRODUCTION}

Rice (Oryza sativa L.) is the staple food of more than three billion people, over half the world population. It provides $27 \%$ of dietary energy and $20 \%$ of dietary protein in the developing world. Rice is cultivated in at least 114 countries, mostly developing, and is the primary source of income and employment of more than 100 million households in Asia and Africa (FAO, 2004). Landraces, traditional varieties or local varieties, form the foundation on which to build better rice plants.Landraces are generally considered to be a rich source of genetic variation. Furthermore, local varieties provide farmers with alternatives, where modern rice varieties are not well adapted in order to contribute to diversity at the field level. However, the number of traditional varieties being planted has reduced, with a few productive and relatively uniform high-yielding varieties dominating the rice landscape. Traditional rice varieties though had been documented to have contributed to the origin of 1,709 modern varieties in Asia which can be traced to 11,592 traditional varieties. The pedigrees of IRRI breeding lines and varieties until 1994 can be traced to hundreds of traditional varieties most from Asian countries (Tran, 2000). Genetic diversity is the basic foundation forspecies survival. The processes of recombination and gene mutation guarantee to the continuous inputs for new variants, as well asthe processes of environmental adaptation and random drift shaping the distribution of genetic diversity in time and space (Brown et al., 1989).

Rice grain quality is the total number of features and characteristics of rice or rice products, which meet the needs of final use. The concept of particle quality includes 
many characteristics from physical properties to biomedification, and milling efficiency, grain shape, ease of cooking, appetite and nutritional properties. In general, it consists of four types, i.e. milling quality, appearance quality, cooking and eating quality, and nutritional quality. Rice quality is evaluated based on various characteristics, which can be classified in several ways. Product characteristics can be tasted,grainy texture or color; or outside the product, such as packaging, branding, or labels. Different market segments can be distinguished between continents, regions, countries and even between socioeconomic groups [Rutsaertet al 2013]. Rice quality experts in 23 countries have identified the top three popular rice varieties in their countries, in some countries, at different sub-national levels; the most commonly rated cooking and eating properties of these varieties have been reported [Calingacionet al 2014]. Consumers may not be able to state clearly the reasons behind their preferences or describe what they like or dislike in food items, but they show the appreciate or value they attach on food in other ways [Spiller et al 2012] such as willingness to pay higher prices for rice with certain quality attributes. The difference in rice price of rice samples of different types of quality shows that grain quality attributes contribute to the price. Product production, processing, and content are good examples of the credit type attributes of that rice variety [Rutsaertet al .2013]. Characterization and evaluation of diversity among traditional varieties will provide plant breeders information that necessary in the identification of initial materials for hybridization to produce varieties with improved productivity and quality.The objective of the study is to evaluate genetic diversity of the traditional rice varieties in HATRI'sgenebank(Vietnamusing morphological characters and microsatellite markers for aroma and yield components AG 4 lines from An Giang province).

\section{MATERIALS AND METHODS}

\section{Plant Materials}

A total of 12 accessions of traditional varieties collected from An Giang province, Vietnam, and conserved in genebank of High Agricultural Technology Research Institute for Mekong delta ( HATRI)in Vietnam. Theoriginal information of these accessions is presented in Table 1.

\section{Agro-morphology Analysis}

11 lines from AG4 traditional varieties were planted in the field at High Agricultural Technology Research Institute for Mekong delta ( HATRI), during the wet season from 2019 to 2020 . Seeds were sown in the raised seedbeds, and 30-day old seedlings were transplanted at one seedling per hill. Hills were established at distances of $20 \times 20 \mathrm{~cm}$. The standard cultural management practices for rice were followed (Bui, 1986).

\section{Quality traits}

A total of 12 lines varieties were evaluated (Table 1) and the following quantitative traits were considered: Panicle length $(\mathrm{cm})$, length of panicle at maturity measured from the base of the plant to the tip of the panicle (taken from 10 random selected primary panicles per accession per replication). Panicles per plant (number), the total number of panicles per plant (from 10 random selected primary panicles per accession per replication). 1000-grain weight (g), weight of 1000 welldeveloped grains at $14 \%$ moisture content (from 5 random selected primary panicles per accession per replication). Days to maturity, days from seeding when $80 \%$ of the grains are fully ripened per replication basis (from 5 random selected primary panicles per accession per replication). Filled grains (number), obtained from counts of total number of filled grains per panicle (from 5 random selected primary panicles per accession per replication). Unfilled grains (number), obtained from counts of total number of unfilled grains per panicle (from 5 random selected primary panicles per accession per replication). Yield obtained from the harvested plants in each replication. Harvested grains were threshed, cleaned, dried, and weighed for each accession per replication. Moisture content per plot was determined immediately after weighing using a moisture meter. Yield $=$ weight of harvested grain $(\mathrm{g}) /$ number of hills harvested $\mathrm{x}$ number of possible hills x MF (of the harvested grain).

\section{Grain quality analyses}

Milled grains underwent assessment of physical traits (grain dimensions, proportion of head rice in milled rice, and chalkiness) and then a test portion of each sample was ground into fine flour(100-mesh) using a Udy Cyclone Sample Mill (model 3010-30, Fort Collins, CO). Reverse osmosis (RO) water and reagent-grade chemicals were used for the chemical analyses.

Physical traits (length, width, and degree of chalkiness) of the milled rice grains were determined using the Cervitec ${ }^{\mathrm{TM}}$ 1625 Grain Inspector (FOSS, Denmark). Grain shape was calculated based on the length-to-width ratio of the grains. The proportion of head rice $(\%)$ in the milled rice was determined by measuring the number of grains that are $75 \%$ intact after a test portion $(100 \mathrm{~g})$ of milled rice was sorted using a shaking sieve; the rest are broken grains $(\%)$.

The AAC of isolated rice starch was analysed by using the iodine reagent method [AACC International.1999]. Briefly, exactly $25 \mathrm{mg}$ rice flour was gelatinized overnight in $2 \mathrm{ml}$ of $1.0 \mathrm{~N} \mathrm{NaOH}$ in a water bath set at $50^{\circ} \mathrm{C}$. The 
solution was boiled in the water bath for $10 \mathrm{~min}$ and then cooled to room temperature. The cooled solution was extracted three times with $5 \mathrm{ml}$ of butanl:petroleum ether (1:3) to remove the lipid, after which $1.5 \mathrm{ml}$ of $0.4 \mathrm{~N} \mathrm{KI}$ was added to the solution and mixed. The ACwas determined in duplicating with an ART-3 Automatic Titrator, according to the manufacturer's instruction (Hirama Laboratories, Japan) in which $1.57 \mathrm{mM} \mathrm{KIO}_{3}$ was titrated at a speed of $2.5 \mu \mathrm{l}$ per s to the starch solution. The titration terminal was automatically detected with a sensitivity setting of 3 , and the used volume of $\mathrm{KIO}_{3}$ was transformed into amylose content. Standard amylose solutions were prepared as checks by dissolving pure amylose and amylopectin in distilled water [Tan YF et al 1999].

\section{Gelatinisation temperature}

GT was determined using the alkali digestion test [Little RR et al 1958]. A duplicate set of six whole-milled kernels without cracks was selected and placed in a plastic box $(5 \times 5 \times 2.5 \mathrm{~cm}) . \quad 10 \mathrm{~mL}$ of $1.7 \% \quad(0.3035 \mathrm{M}) \quad \mathrm{KOH}$ solution was added. The samples were arranged to provide enough space between kernels to allow for spreading. The boxes were covered and incubated for $23 \mathrm{~h}$ in a $30^{\circ} \mathrm{C}$ oven. The starchy endosperm was rated visually based on a seven-point numerical spreading scale as a standard evaluation system for rice [IRRI .2013]. According to the ASV score, GT of rice grains can be classified into four groups: high (1-2), high-intermediate (3), intermediate (45), and low (6-7) [Juliano B et al .1985].

\section{Gel consistency}

Gel consistency was determined as previously described [34].Rice flour $(100 \mathrm{mg})$ was mixed with ethyl alcohol $(0.2 \mathrm{~mL})$ containing $0.025 \%$ thymol blue and $0.2 \mathrm{M}$ potassium hydroxide $(2 \mathrm{~mL})$ and heated in a boiling water bath for 8 minutes. After heating,the sample tubes were allowed to cool in an ice-water bath and immediately laid horizontally on the table. Gel consistency was measured by the length of the cold rice paste in the culture tube held horizontally for one hour. Hard, medium, and soft gel standards such Nang Nhen, Khoadawmali105, are respectively included in every set.

\section{Aroma}

The current definition of aromatic rice is the presence of the volatile compound 2-acetyl-1-pyrroline (2AP). This was quantified at HATRI using gas equipped with a flame ionisation detector [35]. For those rice samples not measured at IRRI, aroma was determinedby smelling and tasting cooked grains. Volatile analysis of aromatic rice by gas chromatographymassspectrometry (GCMS).Volatile compounds in the aromatic rice from Iran, Pakistan,India, and the Greater Mekong Sub-region (GMS) were
analysed.Headspace volatile compounds of selected aromatic rice werecollected by solid phase microextraction using a $65 \mathrm{~mm}$ polydimethylsiloxane-divinylbenzenefibre (Supelco, Bellefonte, USA)and analysed using GC-MS (GC 8000, Fisons Instruments, Cheshire, UK)[36]. GCMS raw data were processed usingMetAlign [37] to extract and align the mass signals, and MSClust[38] to remove signal redundancy per metabolite and reconstructmass spectra. The PCA plot was constructed using SIMCA-P 12.0(Umetrics AB, Umeau, Sweden). The seeds from AG4 plants were manually dehulled. The seedsfrom each line were treated by Satakedehuller. They were milled by testmiller for one hour. Ten seeds from each line plant were individually ground for 10 seconds witha medium speed by Wil grinder. Rice powder of each grain was placed in an individual $5 \times 5 \mathrm{cmplastic}$ box. To each box, 500 ul of diluted alkali (1.7\%) was added and covered immediately. Thetreated samples were placed at room temperature for 30 minutes. The boxes opened one by one, andaroma was scored by smelling. The heterozygotes were recognized based on the presence of aromaticand nonaromatic grains in lines progeny test. When all ten seeds of individual plant werearomatic, the individual was considered as homozygous for aroma. If the ten seeds of individual plant were non-aromatic otherwise, the individual would be considered as homozygous for nonaroma. Presence of aromatic and non-aromatic seeds inlines indicated heterozygous nature of plant. Due toimportance and accuracy of the phenotyping in mapping process, particularly in bulk-segregantanalysis, additional 30 seeds from each homozygous aromatic and homozygous nonaromaticplants were analyzed. It was done to assure the accuracy of phenotyping. Due to the importance and accuracy of phenotying in mapping process, rice leaves were also evaluatedat tillering stage. Ten leaves were sampled from individual plants at tillering and cut into $5 \mathrm{~mm}$ longpieces. They were put into a capped glassware and stored at $-20^{\circ} \mathrm{C}$ before aroma evaluation. Onehour was measured from each frozen leaf sample, by putting into a capped test tube, and mixed with $5 \mathrm{ml}$ of $1.7 \%$ $\mathrm{KOH}$ solution for 10 minutes at $50^{\circ} \mathrm{C}$. Four to five panelists were asked to classify thesamples as either aromatic or non-aromatic by their own smell.

\section{DATA ANALYSIS}

Analysis of variance.

The agro-morphological data collected were initially analyzed through analysis of variance to verify genetic variation in the traits measured. The few traits with insignificant genetic variation, based on the F-test, were not considered for further analyses. 


\section{RESULTS AND DISCUSSION}

Without understanding of consumer preference for rice grainquality, wide adoption of any newly developed rice variety is notguaranteed. Hence, identifying the grain traits that governacceptance is important to guide a successful breeding program.Quality attributes of the most popular rice varieties consumed inthe countries and provinces in Asia, as well as for some of the ricegrowing countries in other continents have been collected.Currently, rice grain quality is classified in terms of its physical, taste, and visual characteristics. The physical appearance ofthe grain defines its price in the market.

A gene aroma located on chromosome 8 has been identified as a fragrance gene (Bradbury et al 2005; Shu et

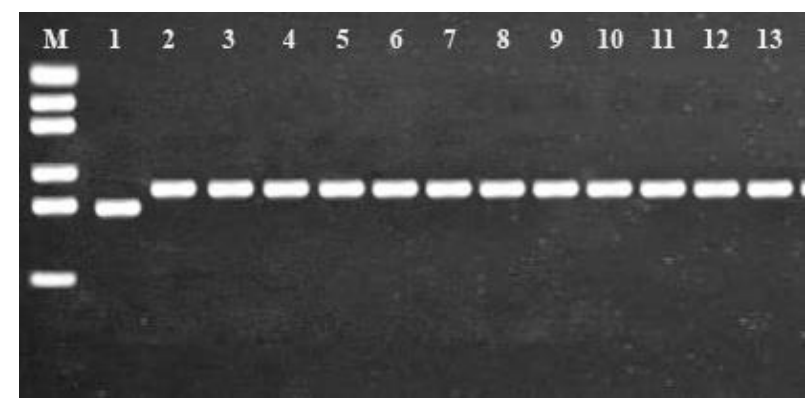

A al 2008), Lang and ctv. in 2008, confirmed the close link between the RG28 directive and fgr $(5.8 \mathrm{cM})$ on chromosome 8 and identified two locus for the RM223 and RG28 fragrances. The target gene chosen to perform this experiment was the aroma gene on chromosome 8. Gene that is tightly linked on chromosome 8 marked by the molecular marker RM 223. This marker is 200-210bp in size and is used as a DNA mold to establish specific primer pairs. These pairs will amplify smaller pieces of DNA,crediting for PCR method. These small pieces of DNA are called SSR. Then conduct an amplification test on the $3 \%$ agarose gel in a TBE $1 \mathrm{X}$ solution. The result is shown in Figure 1a. On Figure 1A there is only 1 line of 100 for fragrance along with the molecular size of KDM 105.

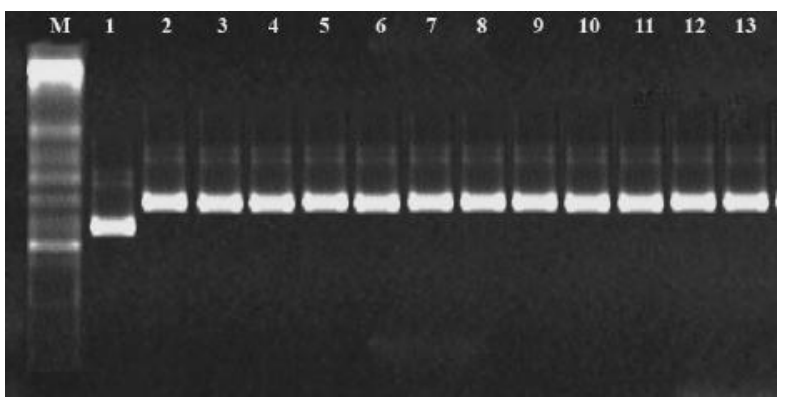

B

Fig.1: (A) PCR product of the RM223 detected 13 AG lines4(3-13) linked to the aroma gene on chromome 8, positioning two size 200bp (1: Nang Nhen); and 210bp(2: KDM 105), on the agarose gel $3 \%$. (B) PCR product of the RM223 molecular detected on 13 AG lines 4(3-13) linked to the aroma gene on chromome 8, positioning two size 190bp (1: Nang nhen ); and 210bp(2: KDM 105), on the agarose gel $3 \%$.

Similarly, [Bradburyet al., 2005] identifying the aroma gene between the Badh2 bymolecular markers. Further studies show that the difference between fragrant rice and non-aromatic rice is due to two molecular markers on the gene that encodes betaine dehydrogenase (BADH2). Indeed, after copying based on the map and sequence of the fgr region, it was found that there is a significant difference in the BADH2 gene sequence between fragrant rice and non-fragrant rice, also there is a mutation in fragrant rice in the 7 th exon region of the BADH2 gene, which leads to the function of losing BADH2 protein. Therefore, BADH2 is likely related to the fgr gene, which controls rice fragrance [Bradburyandet al., 2005]. To verify the function of the BADH2 gene, 3 candidate genes in the fgr region were applied to 8 ag3 seasonal rice selective lines recorded (figure 1B). FMU1-2 Allele Analysis [He and ctv 2015] used as a marker, this marker is sized (190-210bp) and is used as a DNA mold to establish specific primer pairs. On figure $1 \mathrm{~B}$ recorded the breed of non-fragrant, molecularly sized (190bp) and fragrant KDM 105, bearing molecular size (210bp). All lines give a molecular size (210bp) of the same molecular size as the fragrant KDM 105. Fragrance is an important grain quality feature in rice, controlled by mutations in the BADH2 gene. Recorded of lines presence or absence of fragrance. A form set using gas chroma separation to quantrate 2AP content in milled rice samples (Table 1). 2AP content ranges from 0.323 to $3.325 \mathrm{ppm}$.

Table 1. Evaluation of fragrance on AG 4 landrace rice varieties by rice reaction with KOH, $2 A P$ and PCR method.

\begin{tabular}{|l|l|l|l|l|l|}
\hline & $\begin{array}{l}\text { Lines ofAG4 } \\
\text { Test (ppm)b }\end{array}$ & $\begin{array}{l}\text { aroma } \\
\text { RM223(bp) }\end{array}$ & $\begin{array}{l}\text { FMU1-2 } \\
(\mathrm{bp})\end{array}$ \\
\hline 1 & 7 & 3,325 & aroma & 210 & 210 \\
\hline 2 & 9 & 1,256 & aroma & 210 & 210 \\
\hline
\end{tabular}




\begin{tabular}{|l|l|l|l|l|l|}
\hline 3 & 10 & 2,912 & aroma & 210 & 210 \\
\hline 4 & 14 & 0,345 & no & 210 & 210 \\
\hline 5 & 18 & 0,323 & no & 210 & 210 \\
\hline 6 & 20 & 0,855 & no & 210 & 210 \\
\hline 7 & 27 & 1,569 & aroma & 210 & 210 \\
\hline 8 & 31 & 1,324 & Aroma & 210 & 210 \\
\hline 9 & 48 & 2,195 & Aroma & 210 & 210 \\
\hline 10 & 56 & 0,768 & No & 210 & 210 \\
\hline 11 & 92 & 1,234 & Aroma & 210 & 210 \\
\hline 12 & $\mathrm{KDM}(\mathrm{Ð} / \mathrm{C})$ & 3,229 & Aroma & 210 & 210 \\
\hline 13 & $\mathrm{NNĐ/c}$ & 0,000 & No & 200 & 190 \\
\hline
\end{tabular}

\section{Evaluation of yield and components yield AG4 in field}

The rice landraces revealed a wide range of phenotypic variation in 8 agronomic traits (Table 1). 1000-grain weight, showed similar at 11 lines .Assessing the yield and components yieldof the AG4 variety in the same field, through a model assessment of 13 elite lines of styling. The AG4 rice variety was also analyzed for aeration properties, the results also showed that the population gave a high genetic purity value on the breed. Particularly, the yieldand panicle numbers per plant, spikelet / hill . are statistically significant, so the conditions of cultivation and conditions of care and fertilizer for the full development of the variety are very important.

Table 2: Yield and components yield of 11 lines from AG4 with two chected

\begin{tabular}{|c|c|c|c|c|c|c|c|c|}
\hline Lines & $\begin{array}{c}\text { Length } \\
\text { panicle } \\
(\mathbf{c m})\end{array}$ & germination(\%) & $\begin{array}{c}\text { No. } \\
\text { panicle/ } \\
\text { hill }\end{array}$ & spikelet/hill & $\begin{array}{c}\text { unfulling/ } \\
\text { hill (\%) })\end{array}$ & $\begin{array}{c}1000 \text {-grain } \\
\text { weight } \\
\text { (gram)- }\end{array}$ & $\begin{array}{c}\text { Grain yield/ } \\
\text { hill(g) }\end{array}$ & $\begin{array}{c}\text { yield } \\
\text { (ton/ha) }\end{array}$ \\
\hline 7 & $27,70 \mathrm{ab}$ & $98,33 \mathrm{a}$ & $9,76 \mathrm{ab}$ & $1104,33 \mathrm{a}$ & $21,62 \mathrm{~d}-\mathrm{e}$ & $25,49 \mathrm{a}$ & $19,32 \mathrm{a}$ & $4,62 \mathrm{a}$ \\
\hline 9 & $26,05 \mathrm{~b}$ & $97,33 \mathrm{a}$ & $9,50 \mathrm{ab}$ & $974,33 \mathrm{c}$ & $23,25 \mathrm{a}-\mathrm{c}$ & $25,04 \mathrm{a}$ & $19,33 \mathrm{a}$ & $4,47 \mathrm{a}$ \\
\hline 10 & $29,16 \mathrm{a}$ & $98,00 \mathrm{a}$ & $10,00 \mathrm{ab}$ & $991,00 \mathrm{~b}$ & $24,86 \mathrm{a}$ & $25,51 \mathrm{a}$ & $18,37 \mathrm{a}-\mathrm{d}$ & $4,41 \mathrm{a}$ \\
\hline 14 & $26,55 \mathrm{ab}$ & $96,66 \mathrm{a}$ & $9,00 \mathrm{ab}$ & $977,00 \mathrm{c}$ & $20,16 \mathrm{de}$ & $25,94 \mathrm{a}$ & $18,28 \mathrm{a}-\mathrm{d}$ & $3,39 \mathrm{~b}$ \\
\hline 18 & $29,05 \mathrm{a}$ & $96,00 \mathrm{a}$ & $9,66 \mathrm{ab}$ & $952,33 \mathrm{de}$ & $24,47 \mathrm{ab}$ & $25,18 \mathrm{a}$ & $19,10 \mathrm{ab}$ & $3,47 \mathrm{~b}$ \\
\hline 20 & $29,61 \mathrm{a}$ & $97,33 \mathrm{a}$ & $10,00 \mathrm{ab}$ & $913,53 \mathrm{~h}$ & $22,46 \mathrm{a}-\mathrm{d}$ & $25,68 \mathrm{a}$ & $18,15 \mathrm{a}-\mathrm{d}$ & $4,51 \mathrm{a}$ \\
\hline 27 & $26,16 \mathrm{ab}$ & $96,33 \mathrm{a}$ & $9,00 \mathrm{ab}$ & $913,33 \mathrm{~h}$ & $20,24 \mathrm{de}$ & $25,56 \mathrm{a}$ & $18,04 \mathrm{a}-\mathrm{d}$ & $4,24 \mathrm{a}$ \\
\hline 31 & $26,33 \mathrm{ab}$ & $96,33 \mathrm{a}$ & $10,00 \mathrm{ab}$ & $960,00 \mathrm{~d}$ & $21,50 \mathrm{~d}-\mathrm{e}$ & $25,10 \mathrm{a}$ & $18,03 \mathrm{a}-\mathrm{d}$ & $4,19 \mathrm{a}$ \\
\hline 48 & $29,00 \mathrm{a}$ & $98,33 \mathrm{a}$ & $10,33 \mathrm{ab}$ & $933,33 \mathrm{f}$ & $23,84 \mathrm{a}-\mathrm{c}$ & $25,26 \mathrm{a}$ & $17,83 \mathrm{~b}-\mathrm{d}$ & $4,21 \mathrm{a}$ \\
\hline 56 & $26,94 \mathrm{ab}$ & $98,00 \mathrm{a}$ & $9,53 \mathrm{ab}$ & $956,00 \mathrm{de}$ & $23,20 \mathrm{a}-\mathrm{c}$ & $25,39 \mathrm{a}$ & $18,73 \mathrm{a}-\mathrm{d}$ & $4,25 \mathrm{a}$ \\
\hline 92 & $26,55 \mathrm{ab}$ & $97,33 \mathrm{a}$ & $8,67 \mathrm{~b}$ & $887,33 \mathrm{i}$ & $19,10 \mathrm{e}$ & $25,34 \mathrm{a}$ & $18,08 \mathrm{a}-\mathrm{d}$ & $4,20 \mathrm{a}$ \\
\hline KDM(cheked) & $28,99 \mathrm{a}$ & $95,3 \mathrm{~b}$ & $12,2 \mathrm{a}$ & $1074,5 \mathrm{a}$ & $29,8 \mathrm{~b}$ & $27,4 \mathrm{a}$ & $17,70 \mathrm{ab}$ & $4,10 \mathrm{a}$ \\
\hline NN( & $26,40 \mathrm{ab}$ & $96,53 \mathrm{a}$ & $9,00 \mathrm{ab}$ & $879,40 \mathrm{i}$ & $22,00 \mathrm{~b}-\mathrm{d}$ & $25,00 \mathrm{a}$ & $17,35 \mathrm{~d}$ & $3,37 \mathrm{~b}$ \\
\hline Checked) & 26 & $\mathbf{8 , 4 8}$ & $\mathbf{0 , 5 7}$ & $\mathbf{6 , 9 0}$ & $\mathbf{3 , 1 6}$ & $\mathbf{5 , 1 4}$ & $\mathbf{1 3 , 1 7}$ \\
\hline CV (\%) & $\mathbf{3 , 9 5}$ & $\mathbf{2 , 3 6}$ & & &
\end{tabular}

The promising lines of the AG 4 variety are planted and assess the yield and yield components. The results showed that these lines had more equal and evener length panicle than the opposition, the lines were quite good dust blooms, the number of particles / dusts was quite good, and the ratio of panicle was average. In terms of recorded 
productivity: AG 4 lines have quite high productivity, higher than NangNhen (3.37 tons/ha) and KDaw Mali 105 is (4.1 tons/ ha), of which line 7 gives the highest yield (4.62 tons / ha).

Evaluation of rice quality appearance Homity in physical characteristics, such as the length and width of the rice sample can play an important role in the willingness of consumers to pay for rice. When analyzing the size of rice grains is evaluated according to the IRRI standard scale.
AG4 seed record size has a long rice grain size fluctuation of $11.22-11.48 \mathrm{~mm}$ rice grains fluctuation from 7.28$8.67 \mathrm{~mm}$. This is a very long group of rice grains. Analysis of the chalkiness ratio of AG 4 lines noted: most lines do not have chalkiness except lines 9 and 10 for a 0 -word $(99 \%)$ chalkiness ratio in order(Table2). Evaluation of rice and rice grain sizes of 12 samples of AG 4 varieties served and 2 types of confrontation.

Table 2. Evaluation rice grain sizes of 12 lines from $A G 4$ and 2 varieties checked

\begin{tabular}{|c|c|c|c|c|c|c|c|c|}
\hline lines & $\begin{array}{l}\text { Hull } \\
\text { length( } \\
\mathrm{mm})\end{array}$ & $\begin{array}{l}\text { Hull } \\
\text { wide(mm } \\
\text { ) }\end{array}$ & $\begin{array}{l}\text { Kernel } \\
\text { length(m } \\
\mathrm{m})\end{array}$ & $\begin{array}{l}\text { Kernel } \\
\text { wide }(\mathrm{mm})\end{array}$ & Score0 & Score1 & Score 5 & Score9 \\
\hline 7 & 11.36 & 2.62 & 7.49 & 2.18 & 100 & 0 & 0 & 0 \\
\hline 9 & 11.18 & 2.57 & 7.82 & 2.09 & 99 & 1 & 0 & 0 \\
\hline 10 & 11.48 & 2.74 & 8.05 & 2.17 & 100 & 0 & 0 & 0 \\
\hline 14 & 11.29 & 2.68 & 7.28 & 2.1 & 99 & 1 & 0 & 0 \\
\hline 18 & 11.42 & 2.61 & 8.05 & 2.1 & 100 & 0 & 0 & 0 \\
\hline 20 & 11.36 & 2.62 & 7.99 & 2.08 & 100 & 0 & 0 & 0 \\
\hline 27 & 11.31 & 2.78 & 7.67 & 2.21 & 100 & 0 & 0 & 0 \\
\hline 31 & 11.4 & 2.5 & 7.99 & 2.16 & 100 & 0 & 0 & 0 \\
\hline 48 & 11.29 & 2.56 & 7.93 & 2.11 & 100 & 0 & 0 & 0 \\
\hline 56 & 11.48 & 2.36 & 8.67 & 2.16 & 100 & 0 & 0 & 0 \\
\hline 92 & 11.42 & 2.5 & 7.99 & 2.22 & 100 & 0 & 0 & 0 \\
\hline $\begin{array}{l}\text { KhaoDawMali } \\
\text { 105(Checked) }\end{array}$ & 11,48 & 2,65 & 8,98 & 2,22 & 100 & 0 & 0 & 0 \\
\hline $\begin{array}{l}\text { NàngNhen(Ch } \\
\text { ecked) }\end{array}$ & 7,15 & 2,56 & 6,10 & 2,11 & 20 & 15 & 34 & 31 \\
\hline
\end{tabular}

\section{Cooking characteristics}

Besides the quality of appearance, AG4 lines are also rice qualities. In 12 selective line samples, through amylose content analysis and noted: amylose content most lines give low levels. The lowest recorded amylose content was line $10(17.3 \%)$. Gel strength (AC) is a good measure of ground rice plasticity and determines softness after cooking. It is a simple and sensitive quick inspection to determine the quality of rice when ingested supplements for AC. AC rice can be distinguished by softness measured by gel barrier (associated with amylose content). Gel strength barrier directly affects the texture of rice, so 
cooked rice, gel durability hardens faster than soft gel properties. The line noted good gel durability soft rice. Lake temperature (GT) determines the absorption of water and time for cooking. GT is the temperature at which starch particles suck up water and begin to bulge. Most lines have special characteristics that were preferred in the polished grain of AG 4 rice: (1) a 'greasy' look without any abdominal white, (2) an entire rice grain, (3) fully developed and uniform kernel, and (4) neither too soft nor too hard when crushed under the teeth. The characeristics of the cooked rice for which it was valuable: (1)individuality of the cooked grain without bursting, and (2) sweetness and a special fragrance of the cooked product.
Grinding Quality Assessment - Analysis of Milling Rate: A review of the percentage of raw rice shows that line 7 has a fairly high percentage of raw rice $52.1 \%$, quite good compared to the control variety of $45.7 \%$. The percentage of raw rice is also affected by post-harvest treatment, storage time and conditions, and milling.

Nutritional Qualities Assessment - Protein Analysis: The quantity and type of protein are important factors in rice nutrition. Various factors affect the content of rice proteins: climate and environment, and the number of fertilizers applied, the duration of maturity, the degree of milling, and the characteristics of the breed. The protein content of rice varieties ranges from 6.7 to $8.6 \%$. Lines 7 and 56 have the highest protein content $(8.5-8.6 \%)$ in order.

Table3: Quality analysis of 8 lines of recovered $A G 3$ and 2 control lines

\begin{tabular}{|c|c|c|c|c|c|c|c|c|}
\hline lines & $\begin{array}{c}\text { amylose } \\
(\%)\end{array}$ & $\begin{array}{c}\text { Gelatinisation } \\
\text { temperature } \\
(\mathbf{c a ̂ ́ p})\end{array}$ & $\begin{array}{c}\text { Gel } \\
\text { consistency } \\
(\mathbf{m m})\end{array}$ & $\begin{array}{c}\text { \% brown } \\
\text { rice }\end{array}$ & $\begin{array}{c}\text { \% white } \\
\text { rice }\end{array}$ & $\begin{array}{c}\text { \% head } \\
\text { rice }\end{array}$ & protein (\%) & $\begin{array}{c}\text { chackiness } \\
\text { (cấp) }\end{array}$ \\
\hline 7 & $18.6 \mathrm{bc}$ & 5 & $79.1 \mathrm{a}$ & $85.3 \mathrm{a}$ & $77.6 \mathrm{a}$ & $52.1 \mathrm{a}$ & $8.5 \mathrm{a}$ & 0 \\
\hline 9 & $18.5 \mathrm{bc}$ & 5 & $76.5 \mathrm{~cd}$ & $84.1 \mathrm{ab}$ & $74.8 \mathrm{a}-\mathrm{c}$ & $45.6 \mathrm{e}$ & $6.7 \mathrm{~b}$ & 0 \\
\hline 10 & $17.3 \mathrm{~b}$ & 5 & $74.7 \mathrm{ef}$ & $82.1 \mathrm{ab}$ & $76.5 \mathrm{ab}$ & $51.2 \mathrm{ab}$ & $8.0 \mathrm{a}$ & 0 \\
\hline 14 & $18.5 \mathrm{bc}$ & 5 & $75.2 \mathrm{de}$ & $80.1 \mathrm{~b}$ & $74.2 \mathrm{a}-\mathrm{c}$ & $50.3 \mathrm{bc}$ & $8.2 \mathrm{a}$ & 0 \\
\hline 18 & $18.6 \mathrm{ab}$ & 5 & $74.5 \mathrm{ef}$ & $84.3 \mathrm{ab}$ & $76.5 \mathrm{ab}$ & $42.3 \mathrm{f}$ & $7.5 \mathrm{ab}$ & 0 \\
\hline 20 & $19.4 \mathrm{c}$ & 5 & $78.5 \mathrm{ab}$ & $80.2 \mathrm{ab}$ & $74.2 \mathrm{a}-\mathrm{c}$ & $50.6 \mathrm{bc}$ & $7.6 \mathrm{ab}$ & 0 \\
\hline 27 & $18.3 \mathrm{ab}$ & 5 & $77.2 \mathrm{bc}$ & $80.3 \mathrm{ab}$ & $73.6 \mathrm{a}-\mathrm{c}$ & $49.5 \mathrm{~cd}$ & $7.9 \mathrm{a}$ & 1 \\
\hline 31 & $18.6 \mathrm{ab}$ & 5 & $79.5 \mathrm{~g}$ & $83.4 \mathrm{ab}$ & $74.5 \mathrm{a}-\mathrm{c}$ & $48.7 \mathrm{~d}$ & $7.8 \mathrm{ab}$ & 0 \\
\hline 48 & $18.5 \mathrm{ab}$ & 5 & $75.4 \mathrm{~h}$ & $84.5 \mathrm{ab}$ & $75.6 \mathrm{a}-\mathrm{c}$ & $44.6 \mathrm{e}$ & $7.4 \mathrm{ab}$ & 0 \\
\hline 56 & $18.8 \mathrm{bc}$ & 5 & $79.8 \mathrm{a}$ & $81.6 \mathrm{ab}$ & $70.3 \mathrm{c}$ & $45.6 \mathrm{e}$ & $8.6 \mathrm{a}$ & 0 \\
\hline 92 & $18.8 \mathrm{bc}$ & 5 & $75.7 \mathrm{~h}$ & $82.5 \mathrm{ab}$ & $71.2 \mathrm{bc}$ & $40.5 \mathrm{~g}$ & $7.5 \mathrm{ab}$ & 0 \\
\hline KDM105(Đ/C) & $18.7 \mathrm{bc}$ & 5 & $79.2 \mathrm{a}$ & $82.7 \mathrm{a}$ & $72.4 \mathrm{a}$ & $45.5 \mathrm{bc}$ & $8.1 \mathrm{bc}$ & 0 \\
\hline Nang nhen & $24.9 \mathrm{a}$ & 3 & $48.6 \mathrm{c}$ & $82.6 \mathrm{a}$ & $74.2 \mathrm{a}$ & $45.7 \mathrm{bc}$ & $8.2 \mathrm{bc}$ & 0 \\
\hline$(\mathrm{D} / \mathrm{C})$ & & & & & & & & \\
\hline
\end{tabular}

\section{DISCUSSION}

Preference for grain size and shape vary from one group of consumers to the other. Some ethnic groups prefer short bold grains, some prefer medium long grains, and long slender grains are highly priced by others. In general, long grains are preferred in Vietnam subcontinent,but in Southeast Asia, the demand is for medium-to-medium long rice. In temperate areas, short grain varieties are prevalent. There is a strong demand for long grain rice for the international market (Singh et al 2000). Usually, the quality of rice grains is evaluated through consumers and is therefore used as some first choice criteria in improvement programs [Grahamandctv 2002; Tomlins and et al 2007]. Fragrant rice varieties (aromatic rice) account for a significant proportion of the exported rice market with many different levels, including Jasmine rice and Basmati rice. These two types of rice play a key role in the production of world fragrant rice (Mahajan, and ctv. 2018) on AG4 lines analysis recorded all three analyses identifying line 7 for the best aroma. On the other hand, the particle shape is based on the ratio of length to width [Grahamandet al 2002]. The classification of rice samples based on size and shape is not standardized across different countries and different markets [Council of the 
European Eunion .2003; Dela Cruz and et al 2000]. The classification system is regularly used by breeding programs. Thus, according to the breed standard AG 4 is enormously long breed (the longest is line 10 and line 56). Rice grain shapes, likewise, can be described based on the usual range of values used in IRRI: tapering $(\leq 2.0)$, average (2.1-3.0) and slender (> 3.0) [Dela Cruz and ctv 2000]. For most lines belong to the average group in terms of particle width. The chalkinessrepresents poor quality in many segments of the rice market; therefore, these types of rice take the lower market price [Fitzgerald and ctv 2009]. Rice grains are classified based on the ratio ofchakiness: none $(0 \%)$, small $(<10 \%)$, average $(10-20 \%)$, and large $(>$ 20\%) [Fitzgerald and ctv 2009; Lang et al 2015]. Rice grain size is measured using photo enlargers and transparent rulers [Lang et al 2015]. AG4 rice-like samples are considered vastly lowchakinessratio.

The three parameters considered the most important in evaluatiing the cooking quality of many types of rice are: amylose content (AAC), gel durability (GC) and lake temperature (GT). As AAC increases, cooked rice grains tend to get harder and harder [Lang .2015]. Subgroup $\mathrm{AAC}$, rice can be grouped into five layers: wax (0-2\%), very low (3-9\%), low (10-19\%), medium grade (20-25\%), and high (> 25\%) [26].For seasonal rice line 100 was rated to have a lower amylose content than the other lines in table 3. Although a recent study suggests that these AAC classes can be broken down [Calingacionet al 2014]. There are cases where rice materials of the same type of AAC are very different in hardness. In these cases, GC is used as an additional test for the level of rice hardness when cooked. Rice can be classified into three groups based on GC: hard rice $(\leq 40 \mathrm{~mm})$, medium $(41-60 \mathrm{~mm})$, and soft $(>61 \mathrm{~mm})$ [Graham, and ctv 2002]. Analysis of 8 AG 4 lines recorded shows that most belong to the rice soft group.

On the other hand, milled rice/brown rice kernel appearance and dimensions determine the price in the market. Milling quality determines the final yield and fracture rate of milled rice, which is a concern of consumers and farmers. The three main parameters, the recovery of brown rice (the ratio of brown rice to raw rice), the recovery of ground rice (the ratio of ground rice to raw rice) and the recovery of raw rice (the ratio of raw rice to raw rice) are used to assess the quality and effectiveness of the milling process. Line 7 gives a high percentage of rice over $50 \%$. Pure lines of selection from AG 4 submited at NCBI with sequences were determined directly using thedideoxynucleotide chain-termination method with a DNA Sequencer (ABI PRISM 3130xl; Applied Biosystems/) and BigDye Terminator (version 3.1) cycle sequencing kit (RR-100, Applied Biosystems), according to the manufacturer's instructions. Obtained
rbcL gene sequence was submitted to NCBI /GenBank database(Accession no. MT177967:AG4).

\section{CONCLUSION}

Through aroma analysis on 11 lines from AG 4 series recorded all three evaluation methods for aroma: rice reaction test with $\mathrm{KOH}$, calculated 2-acetyl1-pyrroline (2AP) and PCR method with two markers RM223 and FMU1-2 recorded to select the best fragrant line, which is line 7 followed by line 10 and line 48 . When calculating qualities through shape evaluation, the length and width of AG 4 are high. As well as a good level chakiness. Rice quality analysis recording amylose content is recorded that most of the low content on AG4 lines. This proves the delicious lines of rice. Milling quality determines the final yield and fracture rate of milled rice. Recorded lines of $7,10,14$, and 20 for high milling rates above $50 \%$. Protein content of rice varieties ranges from 6.7 to $8.6 \%$. Lines 7 and 56 have the highest protein content $(8.5-8.6 \%)$ inrespectively. The protein content of rice varieties ranges from 6.7 to $8.6 \%$. Lines 7 and 56 have the highest protein content $(8.5-8.6 \%)$ in respectively. -Analyzing yield and yield component, line 9 gives the highest yield ( 4.47 tons / ha, next is line 7 (4.62t / ha).

\section{ACKNOWLEDGEMENTS}

The authors are extremely grateful to An Giang Department of Science and Technology for providing funding to implement this topic. Thanks are due to HATRI and our colleagues in the Genetics and Plant Breeding Division for their support and valuable suggestions.

\section{REFERENCES}

[1] AACC International.1999. Approved Methods of Analysis, 11th Ed. Method 61-03.01. Amylose content of milled rice. Approved October 15, 1997; reapproved November 3, 1999. AACC International, St. Paul, MN, U.S.A.

[2] Bradbury MT, Fitzgerald TL, Henry RJ, Jin QS and Waters LE .2005. The gene for fragrance in rice. Plant Biotechnol J 3:363-370.

[3] Buttery RG, Ling LC, Juliano BO. 1982. 2-acetyl-1pyrroline: an important aroma component of cooked rice. Chem Ind 23:958-959.

[4] Council of the European Eunion. Council Regulation (EC) $1785 / 2003$ on the common organisation of the market in rice. Official Journal of the European Union. 2003;270: 96113.

[5] Cuevas RP, Fitzgerald MA. Genetic Diversity of Rice Grain Quality In: Caliskan M, editor. Genetic Diversity in Plants. InTech; 2012. pp. 285-310. Available: http://www.intechopen.com/books/genetic-diversity-inplants 
[6] Cuevas RP, Daygon VD, Corpuz HM, Nora L, Reinke RF, Waters DLE, et al. Melting the secrets of gelatinisation temperature in rice. Functional Plant Biology. 2010;37: 439 doi: $10.1071 / \mathrm{FP} 09258$

[7] Calingacion M, Laborte A, Nelson A, Resurreccion A, Concepcion JC, Daygon VD, et al. Diversity of global rice markets and the science required for consumer-targeted rice breeding. PloS one. 2014;9: e85106 doi: $\underline{10.1371 / \text { journal.pone.0085106 }}$ [PMC free article] [PubMed]

[8] Dela Cruz NM, Khush GS. Rice Grain Quality Evaluation Procedures In: Singh RK, Singh US, Khush GS, editors. Aromatic Rices. New Delhi, India: Mohan Primlani; 2000. pp. 15-28.

[9] Fitzgerald MA, Resurreccion AP. Maintaining the yield of edible rice in a warming world. Functional Plant Biology. 2009;36: 1037 doi: 10.1071/FP09055

[10] Graham R. A Proposal for IRRI to Establish a Grain Quality and Nutrition Research Center. Los Baños, Philippines; 2002. Report No.: 44.

[11] He, Q., \& Park, Y. J. (2015). Discovery of a novel fragrant allele and development of functional markers for fragrance in rice. Mol Breed, 35, 217. https://doi.org/ 10.1007/s11032-015-0412-4.

[12] Mahajan G, Matloob A, Singh R. 2018. Basmati Rice in the Indian Subcontinent: Strategies to Boost Production and Quality Traits. Advances in Agronomy. Elsevier Ltd, pp 159-213.

[13] Little RR, Hilder GB, Dawson EH. Differential effect of dilute alkali on 25 varieties of milled white rice 1958. Cereal Chemistry. 1958;35:111-26. [Google Scholar

[14] IRRI. Alkali digestion In: IRRI, editor. Standard Evaluation System (SES) for rice, 5th Ed. Los Banos, Manila, Philippines: International Rice Research Institute (IRRI); 2013. p. 46. [Google Scholar]

[15] Nguyen Thi Lang and Bui Chi Buu.2008.DEVELOPMENT OF PCR-BASED MARKERS FOR AROMA (fgr) GENE IN RICE (Oryza sativa. L.). Omonrice 16: 16-23 (2008).

[16] Nguyen thiLang .2002. Basic methods in biotechnology research, Agriculture publish, Ho Chi Minh City HCM.

[17] Nguyen thi Lang.2015. The report: Research on selecting rice varieties for export for mekong delta 2011-2015. Ministry-level summary report

[18] Petrov M, Danzart M, Giampaoli P, Faure J, Richard H. 1996. Rice aroma analysis: discrimination between a scented and a non-scented rice. Sci Aliments (16):347-360

[19] Rutsaert P, Demont M, Verbeke W. Consumer Preferences for Rice in Africa In: Wopereis MCS, Johnson D, Ahmad N, Tollens E, Jalloh A, editors. Realizing Africa's Rice Promise. Boston: CABI Publishing; 2013. pp. 293-301.

[20] Singh N, Sodhi NS, Kaur M, Saxena SK. Physicochemical, morphological, thermal, cooking and textural properties of chalky and translucent rice kernels. Food Chemistry. 2003;82: 433-439. doi: $\underline{10.1016 / \mathrm{S} 0308-}$ 8146(03)00007-4.

[21] -Sing .K.R , US Singh, G.S.Khush .2000. Aromatic rices .Published by Mohan Primlani for Oxford \& IBH Publishing Co. Pvt. Ltd., 66 Janpath, New Delhi 110001.
[22] -Spiller K. It tastes better because ... consumer understandings of UK farmers' market food. Appetite. 2012;59: 100-7. doi: 10.1016/j.appet.2012.04.007 [PubMed]

[23] Shu Xia Sun; Fang Yuan Gao; Xian Jun Lu; Xian Jun Wu ,Xu Dong Wang; Guang Jun Ren; Hong Luo.2008.Genetic analysis and good gene mapping of fragrance in rice (Oryza sativa L. Cyperales, Poaceae). Genet. Mol. Biol. vol.31 no.2 2008. https://doi.org/10.1590/S1415-48572008000300021.

[24] Tan YF, Li JX, Yu SB, Xing YZ, Xu CG, Zhang Q. The three important traits for cooking and eating quality of rice grains are controlled by a single locus in an elite rice hybrid, Shanyou 63. TAG Theoretical and applied genetics Theoretische und angewandte Genetik. 1999;99:642-8. [PubMed] [Google Scholar]

[25] -Tomlins K, Manful J, Gayin J, Kudjawu B, Tamakloe I.2007.. Study of sensory evaluation, consumer acceptability, affordability and market price of rice. Journal of the Science of Food and Agriculture. 2007;87: 15641575. doi: $10.1002 / \mathrm{jsfa} .2889$.

[26] Juliano B. Criteria 1985.Test for rice grain quality Rice chemistry and technology. Saint Paul: American Association of Cereal Chemists (AACC) 1985. p. 443513. [Google Scholar] 